\title{
TEMA LIVRE
}

\section{Os Papéis Sociais dos Homossexuais Masculinos na Angola Antiga: uma análise comparada dos ngangas na literatura e na história}

\section{Sílvio Geraldo Ferreira da Silva ${ }^{1}$}

Resumo: A homossexualidade masculina, apesar do desconhecimento, era uma realidade na Angola Antiga. Os ngangas eram curandeiros, conselheiros e chefes espirituais homossexuais que possuíam um grande prestígio na sociedade $m b u n d u$. O silenciamento destes sujeitos no contexto angolano antigo aconteceu após a presença da Igreja Católica naquele espaço. Com a imposição da moral cristã, os sistemas sociais dos povos locais foram dissolvidos parcial ou totalmente. Este trabalho objetiva resgatar a memória dos ngangas ambundu e iluminar a temática da homossexualidade masculina na Angola Antiga, elementos apagados pela invasão portuguesa. A justificativa desta investigação é a necessidade de se conhecer o passado da diversidade sexual, ou de parte dela, para tentar compreendê-la no presente. Deseja-se que este trabalho seja uma contribuição para pesquisas futuras que também tenham o objetivo de iluminar o passado da homossexualidade em Angola e/ou em qualquer outra localidade do globo.

Palavras-chave: Nganga. Homossexualidade. Angola Antiga. Silenciamento. Igreja Católica.

\section{Introdução}

A homossexualidade na África Antiga é um assunto bastante desconhecido por muitas pessoas e também bem pouco discutido dentro do universo acadêmico. Quando se pensa em diversidade sexual, parece que o assunto é algo que surgiu na atualidade como uma tendência moderna do mundo ocidental. É correto afirmar que existem registros das expressões das sexualidades e identidades sexuais humanas desde a Grécia Antiga, porém é no momento atual que estes sujeitos que fogem ao padrão da heteronormatividade têm ganhado a oportunidade de serem os protagonistas de suas próprias histórias. É na atualidade também que a memória da diversidade tem conseguido sobreviver. "No desdobramento do conceito de sobrevivência, passado e futuro estão justapostos" (SOUZA; LYZARDO-DIAS; BRAGANÇA, 2014, p. 07).

\footnotetext{
${ }^{1}$ Mestrando em Letras pela Universidade Federal de Lavras - UFLA. Coordenador de Representação da Aliança Nacional LGBTI+ do Município de Lavras - MG. E-mail: silviosilva57@yahoo.com.br.
}

Vol. 03, N. 11, Jul. - Set., 2020 - http://periodicoscientificos.ufmt.br/ojs/index.php/rebeh/index 
Os ngangas, objetos desta investigação, estiveram presentes em diferentes comunidades africanas, sendo conhecidos também como Grandes Mães (CAVAZZI, 1965 ) e/ou Sacerdotes do Sacrifício (AGUALUSA, 2015), porém, para o presente estudo serão abordados apenas os que viveram no seio do povo mbundu, na região da África Central Ocidental. Os primeiros registros destes homens homossexuais são datados do início da colonização portuguesa em Angola. Naquele período, séculos XVI e XVII, a região da África Central mais cara para esta investigação encontrava-se dividida em dois reinos: o Ndongo e a Matamba. Estes dois reinos foram substanciais para a formação de Angola, tanto no quesito territorial quanto cultural, pelo fato de terem sido palco do protagonismo da lendária Rainha Ginga Mbandi Kakombe, que atualmente é um dos nomes mais importantes para a identidade nacional daquele país.

A principal base bibliográfica desta pesquisa é a obra literária A Rainha Ginga: e de como os africanos inventaram o mundo (2015), escrita pelo angolano José Eduardo Agualusa. A obra do autor é muito interessante para pesquisas científicas pela sua riqueza documental. Agualusa teve o cuidado de contemplar, na sua obra supracitada, alguns dos espaços que fizeram parte do Império Português, aproximando Angola e Brasil de maneira bastante interessante. Os ngangas não são os personagens principais de seu romance histórico, porém são abordados como sujeitos importantes nas sociedades onde viviam.

Antonio de Oliveira de Cadornega, em sua obra intitulada História Geral das Guerras Angolanas, claramente, contemplou os conflitos mais importantes que ocorreram no contexto angolano nos idos do século XVII, mas também registrou traços culturais, religiosos e identitários das gentes da região da África Central Ocidental. A obra do soldado português, publicada pela primeira vez no ano de 1680, atualmente é considerada uma das maiores fontes documentais sobre a história de Angola Antiga, por este motivo fará parte do corpus desta investigação. É importante dizer que nem tudo aquilo que está escrito na obra supracitada pode ser tomado como a verdade, pois há a presença da visão eurocêntrica julgadora, por esse motivo haverá o cruzamento do texto mencionado com outras fontes.

A obra Istorica Descrizione de' Tre Regni Congo, Matamba et Angola, de autoria do padre capuchinho italiano Giovanni Cavazzi, contém grandes contribuições históricas 
para estudos sobre a temática, por esse motivo também será abordada de maneira especial nesta pesquisa. O texto de Cavazzi é bastante interessante, pois o autor contemplou muitos detalhes espaciais, naturais e políticos da região da África Central Ocidental. É importante dizer que, como na obra de Cadornega, no texto de Cavazzi é possível notar a visão vertical da Europa sobre a África, e, pelo fato do autor ser um sacerdote católico, há uma demonização evidente da figura dos ngangas pelo fato de serem homens homossexuais.

A presente pesquisa justifica-se pela necessidade de iluminar a figura dos ngangas no cenário angolano antigo. Os ngangas possuíam um local social privilegiado dentro das comunidades em que habitavam, porém, após a disseminação da moral católica, a situação para eles mudou. Esses sujeitos foram perseguidos, torturados e assassinados brutalmente pelo Santo Ofício da Inquisição. Reascender estes personagens é uma obrigação histórica, pois, ao falar sobre eles, rompe-se o silenciamento instaurado pela Igreja Católica e pela moral portuguesa, revelando a importância dos papéis exercidos socio-politicamente pelos ngangas nos contextos sociais de seu povo.

Galliano (1979) definiu o método científico, em geral, de uma maneira interessante quando disse que este é o conjunto de etapas a serem seguidas para que um determinado fim seja alcançado. O mesmo autor também definiu que a técnica é a maneira de fazer a pesquisa da melhor forma possível (GALLIANO, 1979). O método utilizado para a elaboração da presente investigação é a Literatura Comparada, entretanto, esta maneira de se fazer ciência é bastante ampla e carece de mais aporte teórico. Outras palavras de peso para a iluminação da metodologia são as de Carvalhal (2006), pois a autora caracterizou a Literatura Comparada como uma possibilidade investigativa que ambiciona um grande alcance, podendo ser utilizada em diferentes universos das expressões humanas, de acordo com o que deseja o pesquisador. Assim, percebe-se que as palavras de Galliano (1979) e Carvalhal (2006) se complementam e ilustram o que vai acontecer neste artigo, pois o presente contará com a literatura, a história e a ciência histórica e literária para a disseminação do conhecimento sobre a figura dos ngangas.

Objetiva-se, com este estudo, iluminar um pouco mais sobre a existência da homossexualidade masculina na Angola Antiga por meio da figura dos ngangas. Os citados sujeitos possuíram um protagonismo de grande importância na sociedade mbundu, como mencionado anteriormente, pois eram curandeiros e conselheiros dos 
chefes de Estado, o que lhes proporcionava um grande prestígio por parte de todos da comunidade. A presença da Igreja Católica significou um sério problema para os ngangas, por este motivo também comentaremos o impacto da dita instituição religiosa no contexto sociocultural mbundu.

Estudos desta natureza têm se mostrado necessários para expandir o conhecimento sobre a diversidade sexual em tempos anteriores e em espaços distantes. Iluminar figuras como os ngangas é iluminar parte do passado da diversidade sexual e afirmar que o ser humano é plural em todos os seus aspectos, independentemente do período sóciohistórico. Este trabalho, portanto, é uma remontagem da figura dos ngangas por meio de uma análise comparativa histórico-literária que é justificada pela necessidade de compreender a presença e a importância destes homossexuais em um cenário longínquo territorial e temporalmente. Este trabalho também poderá ser o suporte para estudos futuros, dada a escassez de investigações sobre o assunto.

\section{Os ngangas na obra de Agualusa}

A obra de José Eduardo Agualusa, intitulada A Rainha Ginga: e de como os africanos inventaram o mundo (2015), não fala exclusivamente sobre os ngangas. Ela os contempla de maneira interessante e até expõe os papéis sociais que eles exerciam, porém eles não são as personagens principais, nem mesmo a Rainha Ginga é a protagonista. Francisco José da Santa Cruz, o narrador-personagem, é um padre nascido em Pernambuco que vai para Angola servir à Rainha Ginga como seu secretário. O narrador é o protagonista do romance. Por ser um sacerdote, o começo do enredo está cheio de julgamentos sobre a cultura dos africanos, pois o padre vê atitudes que considera pecaminosas em diversos momentos da sua estadia no Reino do Ndongo. À medida que o tempo passa e ele se encontra em meio aos ambund $u^{2}$, o sacerdote se "contamina" pelo contexto, apaixonando-se por uma mulher da terra e tendo com ela um filho.

É importante dizer que, naquele contexto histórico, os portugueses já chamavam a região dos reinos do Ndongo e da Matamba de Angola, porém os povos da terra chamavam os territórios pelos nomes originais. Assim sendo, o romance de Agualusa

\footnotetext{
${ }^{2}$ Ambundu, na língua dos povos dos Reinos do Ndongo e da Matamba, é a forma de mbundu no plural. Os povos dos citados reinos eram descendentes dos povos bantos, dos quais herdaram, inclusive, a língua.
}

Vol. 03, N. 11, Jul. - Set., 2020 - http://periodicoscientificos.ufmt.br/ojs/index.php/rebeh/index 
chama os territórios pelos nomes da terra - Reino do Ndongo e Reino da Matamba - e também pelo nome de Angola, demonstrando o trânsito da posição do narrador, que começa a história com uma visão bastante eurocêntrica, mas que, ao longo da narrativa, vai se libertando de alguns conceitos e preconceitos para mergulhar naquele novo universo. É interessante dizer que, no romance base desta pesquisa, são recorrentes os termos nganga dia quimbanda ou quimbanda para se referir aos ngangas, desta forma, torna-se necessário dizer que todas as formas remetem ao mesmo grupo de curandeiros homossexuais.

A primeira vez que os ngangas aparecem no romance de Agualusa (2015) acontece quase na metade da história. A obra retorna às figuras deles em outros momentos, com o foco em um personagem específico chamado Hongolo. Esta primeira referência aos ngangas acontece em um momento em que o narrador se encontrava auxiliando os guerreiros da Rainha Ginga que retornaram de uma batalha contra os portugueses. Assim, o romance diz:

No quilombo havia já muitos feridos, dos quais me ocupei, ao lado dos quimbandas e ervanários da rainha. Entre estes quimbandas chamaram-me a atenção uns que se vestem e se comportam como mulheres, aos quais dão os ambundos o nome de nganga dia quimbanda, ou sacerdote do sacrifício (AGUALUSA, 2015, p. 58).

Este primeiro contato do sacerdote brasileiro com os ngangas demonstra a sua surpresa ao conhecer um grupo diferente de tudo o que já tinha visto até então. O próprio romance traz uma breve descrição sobre quem seriam os ngangas e qual o papel deles na comunidade dizendo que:

Trazem estes quimbandas cabelo comprido, muito enredado e descomposto, e a cara sempre bem raspada, que parecem capões. Deitam-se com homens, fazendo com eles o que na natureza fazem as fêmeas com os machos, e com tudo isso são muito respeitados e venerados por toda a gente (AGUALUSA, 2015, p. 58).

A maneira que o padre descreve o grupo é interessante, levando o leitor a vislumbrar o cenário de acontecimento do encontro e a aparência física dos ngangas. $\mathrm{Na}$ descrição, é possível perceber algumas das funções das quais os sacerdotes do sacrifício se incumbiam, como os cuidados com os doentes e feridos, por exemplo. É também 


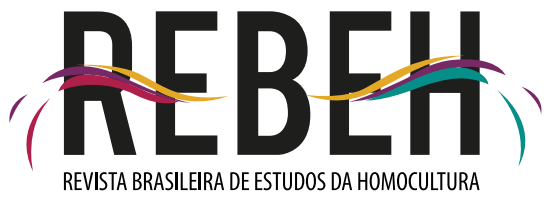

percebido que uma das regras do ministério nganga seria o fato de serem passivos durante

o ato sexual. O enredo do romance prossegue, porém, observaremos, a partir deste ponto, a figura do nganga Hongolo que entra em cena como um personagem importante. É esta personagem quem vai representar o grupo de homossexuais do qual se trata este estudo.

Sobre o citado nganga, o narrador Santa Cruz diz:

\begin{abstract}
Um destes quimbandas, de nome Hongolo, simpatizou comigo, mostrando-me algumas ervas com as quais sarava as feridas, mesmo as que já cheiravam mal. Uma noite repartiu comigo uma bebida amarga. Lembro-me que, embriagado por essa poção, conversei com ele enquanto as estrelas bailavam com a Lua. Conversamos muito, ainda que a essa altura eu mal compreendesse as línguas de Angola, e ele nada falasse de português. Hongolo foi aprisionado pouco depois e só o voltei a ver, muitos anos mais tarde, num arimo a poucas milhas de Luanda (AGUALUSA, 2015, p. 58).
\end{abstract}

O excerto acima apresenta duas questões extremamente caras para esta investigação; o aprofundamento nas funções dos ngangas e a prisão. Uma das funções dos ngangas, que aparece no fragmento apresentado, era a de curandeiros, pois conheciam plantas diversas que eram utilizadas para a promoção da saúde pública. O segundo elemento que o trecho do romance trata é a prisão de Hongolo, porém, o motivo deste acontecimento não fica evidente neste momento, sendo revelado a posteriori. A captura de Hongolo é um ponto interessante a ser pensado, pois, naquele contexto histórico, idos do século XVII, os africanos estavam sendo capturados pelos portugueses para serem enviados ao Brasil Colônia. Naquele momento, estavam sendo escravizadas pessoas de Angola, Congo e Moçambique (SILVA, 1943). Voltando o foco para o nganga Hongolo, observemos o romance:

Não fazíamos outra coisa o dia inteiro senão conversar. Ingo lembrou o caso de um dos quimbandas prediletos da rainha Ginga, Hongolo, o qual terá sido, em determinada ocasião, capturado pelas tropas do capitão António Dias Musungo. Diz-se que escapou do cativeiro transformando-se em cobra. Ingo dava crédito à lenda. Rafael também (AGUALUSA, 2015, p. 152).

Outro detalhe que não pode ser deixado de lado é o fato dos ngangas terem poderes mágicos atribuídos às suas figuras. Além do poder de se transformar em outros seres, "Hongolo dominava a ciência de encantar leões e outras feras, fazendo com que 
estas atacassem os homens" (AGUALUSA, 2015, p. 206), o que abre a possibilidade de comentar que até os portugueses manifestaram interesses nestas habilidades fantásticas, de acordo com o romance. Para ilustrar este interesse dos portugueses sobre as artes mágicas de Hongolo, a obra diz que o governador de Luanda na época, pensou em contratar seus serviços para que mandasse os leões atacar os Flamengos que haviam tomado a capital, porém o plano não deu certo pelo fato do bispo ter se imposto na situação (AGUALUSA, 2015). Este ponto, exposto pelo romance, serve para demonstrar muito bem a aura fantástica que os povos da terra projetavam sobre aqueles curandeiros e ervanários homossexuais e também mostra que os portugueses já estariam sofrendo certa influência sociocultural mbundu. No fragmento apresentado, ainda é possível vislumbrar a credibilidade da qual os ngangas gozavam por meio das palavras dos personagens Ingo e Rafael, que confirmaram acreditar na transformação mágica de Hongolo em cobra.

Uma das partes mais caras para esta investigação é um diálogo entre o narrador Francisco José da Santa Cruz e Hongolo. Este momento do romance consegue desenhar, de maneira bastante clara, a transição pela qual aquele contexto sócio-histórico passava, além de demonstrar uma visão do nganga bastante firme sobre a Igreja Católica. O diálogo é o seguinte:

Hongolo ficou feliz por me ouvir falar em quimbundo. Alegrava-o a minha visita.

— Os padres não gostam de mim, por que vieste?

— Já não sou padre. A Igreja expulsou-me...

— Não te martirizes com isso. Os brancos têm boas obras, mas a Igreja não é uma delas. Por que é que os padres insistem em nos importunar com o seu Deus e o seu Diabo?

— Eles acham que têm o dever de salvar os africanos... (AGUALUSA, 2015, p. 209).

Agualusa faz críticas interessantes em sua obra. No diálogo apresentado acima, pode-se ver a crítica do autor sendo expressa por meio de suas duas personagens, principalmente mediante o nganga Hongolo. Quando o ex padre diz que deixou o sacerdócio, o nganga o consola e diz que a igreja não era uma "boa obra". O mais interessante do diálogo é a interrogação feita por Hongolo: "Porque é que os padres 
insistem em nos importunar com o seu Deus e o seu Diabo?" (AGUALUSA, 2015, p. 209). Esta frase é uma pergunta dentro do romance, porém, é uma crítica forte o suficiente para levar o leitor a construir sentido e questionar a imposição da Igreja Católica naquele contexto. Os ambundu não possuíam em suas crenças as figuras dicotômicas de Deus e Diabo, pois a religiosidade deles partia de outra visão de mundo. A imposição religiosa católica no universo mbundu configura-se, portanto, como um evento desgastante e incômodo. A resposta do ex padre fecha a seção com outra provocação: "Eles acham que têm o dever de salvar os africanos...” (AGUALUSA, 2015, p. 209). Apesar de simples, a frase de Santa Cruz demonstra que o narrador-personagem, naquela altura do romance, tomou outro lugar, evidenciando esta postura ao referir-se aos padres na terceira pessoa do singular.

\section{Os registros de Cadornega e Cavazzi}

Cadornega e Cavazzi elaboraram duas fontes documentais muito importantes. No contexto de suas vidas no continente, precisamente o século XVII, imortalizaram à base de tinta e papel parte da história e das identidades dos povos da região da África Central Ocidental. Mesmo com suas impressões pautadas nos valores europeus, os dois autores fizeram um trabalho à memória angolana pela elaboração de textos tão longos, complexos e minuciosos. Talvez, sem estas duas obras, fosse quase impossível remontar satisfatoriamente o passado dos ngangas de Angola, por este motivo é necessário dizer que estes documentos são substanciais para esta investigação.

A primeira obra a ser abordada nesta seção é Istorica Descrizione de' Tre Regni Congo, Matamba et Angola, de Cavazzi. O autor, bastante detalhista, tratou de descrever os ngangas, porém, suas palavras demonstram a aversão dele à figura dos citados personagens, como pode ser visto:

Entre os feiticeiros, um há que não mereceria ser lembrado, se esta omissão não prejudicasse o conhecimento necessário que eu, por meio deste escrito, pretendo dar aos missionários. Chama-se nganga-ia quimbanda, ou "sacerdote chefe do sacrifício". Este homem, tudo ao contrário dos sacerdotes do verdadeiro Deus, é moralmente sujo, nojento, impudente, descarado, bestial e de tal modo que entre os moradores da Pentápolis teria o primeiro lugar (CAVAZZI, 1965, p. 201). 
O uso de tantos adjetivos depreciativos na descrição de um nganga, cujo nome não é mencionado, demonstra como estes personagens eram vistos sob a ótica do autor. É preciso levar em consideração a visão do sacerdote, pois, para os religiosos, o ato sexual entre dois homens era/é visto como o "pecado nefando". Cavazzi (1965, p. 202) ao se referir ao nganga em questão, em tom de indignação, ainda diz que "não há lei que o condene, como não há ação que não lhe seja permitida". Neste momento, o pronunciamento do religioso evidencia a sua reprovação aos curandeiros homossexuais e também lança luz sobre o fato deles viverem bem e sem sofrer qualquer tipo de retaliação por parte da população local. O fato dos ngangas possuírem tamanha liberdade para fazerem o que quisessem é um detalhe que vai ficando mais compreensível à medida que vamos adentrando no assunto. Prosseguindo, a obra do padre capuchinho também aborda um dos rituais protagonizados pelos ngangas:

\begin{abstract}
Oferecendo o sacrifício propriamente seu, mata um galo, uma serpente e um cão. Então um dos presentes, levando às escondidas a cabeça do cão, corre a escondê-la num buraco. Depois pede ao feiticeiro que a descubra, e se este não se demorar muito na descoberta, fica enormemente conceituado, como se estivesse em contínua comunicação com os espíritos. Todos então o proclamam superior aos demais feiticeiros, chamando-lhe nganga-iaquimbondi (CAVAZZI, 1965, p. 202).
\end{abstract}

Apesar do tom de julgamento ser algo presente na obra de Cavazzi, é preciso reconhecer que o padre explicou muito bem um rito de passagem tradicional para os ngangas de Angola. Ritos de passagem são bastante comuns em comunidades de África. Para os ngangas, o rito descrito pode ser entendido como um processo de crescimento transcendental. A crença dos povos da terra era que se o nganga conseguisse encontrar a cabeça do cão, isto evidenciaria que ele esteve em conexão contínua com os espíritos que o auxiliaram no processo de busca. Na existência de uma busca bem sucedida, o dito feiticeiro se tornaria o mais prestigiado dentre todos daquele grupo. $\mathrm{O}$ trecho de Cavazzi (1965) também é interessante pelo fato de demonstrar que a tradição dos ngangas era bastante sólida e reconhecida pelas sociedades onde viviam.

Um ponto que vale a pena refletir é o de que a manutenção da memória dos ngangas em muito deve à presença do padre italiano em Angola. Talvez o fato de o sacerdote possuir tanta aversão aos "feiticeiros praticantes de sodomia" tenha sido um 


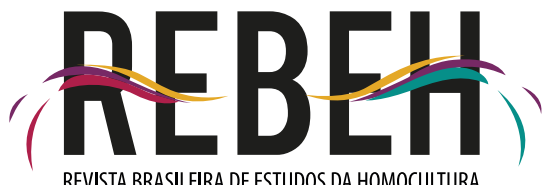 \\ REVISTA BRASILEIRA DE ESTUDOS DA HOMOCULTURA
}

gatilho para que escrevesse sobre eles. O contexto angolano foi bastante inquietante para

Cavazzi, pois, ainda mais naquele momento histórico, relações sexuais entre dois homens era algo inadmissível para a moral cristã. O castigo para o "pecado nefando" certamente seria a morte na fogueira, porém, em Angola, por haver outra visão sobre a homossexualidade por parte dos povos da terra, os ngangas viviam suas vidas naturalmente. Cavazzi (1965, p. 203) também teve o cuidado de registrar como ocorre a cerimônia fúnebre do nganga chefe:

\begin{abstract}
Quando este feiticeiro morre, o mais ancião da seita deve convocar todo o povo para celebrar o seu funeral. Durante a noite, já que esta é propicia para ocultar suas torpezas, devem estar presentes só os inscritos na seita, sendo proibida a presença de outros. Levam então o cadáver para o interior de uma mata e depois de diversas cerimônias execráveis, que alguns dos recém convertidos me revelaram, mas que eu não posso descrever pela sua desonestidade, enterram-no numa cova muito funda. Antes disto, porém, o seu sucessor manda que lhe seja tirado o coração e as entranhas e lhe cortem as extremidades dos pés e das mãos, que eles depois vendem aos pedacinhos, como coisas sagradas e por grande preço.
\end{abstract}

O trecho traz questões que exigem profunda reflexão. Dada a escassez de fontes documentais que abordem mais o assunto, é preciso pensar quais seriam as "diversas cerimônias execráveis" mencionadas por Cavazzi (1965). Uma possibilidade, dado o tom da obra, seria a de que fossem realizados atos necrofílicos com o cadáver do nganga ia quimbondi, entretanto, não se encontrou algo que sanasse essa questão.

Outro ponto que merece reflexão é o fato do cadáver ter órgãos retirados, mãos e pés amputados e ter vendidas todas estas partes por valores altos. É preciso, nesse momento, falar sobre o jogo de búzios para uma melhor compreensão do possível motivo de parte do ritual. Esse jogo consiste em uma leitura adivinhatória alcançada por meio de uma conexão espiritual com o mundo dos mortos e com os Deuses Africanos (OLIVEIRA; MADRUGA, 2019), no qual são utilizadas conchas ou materiais similares. Atendo a atenção nas mãos e nos pés decepados, os ossos destas partes - falanges e outras - depois de secos eram utilizados para a adivinhação por meio de uma prática que se assemelhava ao jogo de búzios. Os ossos eram lançados sobre uma superfície e, assim como no jogo de búzios, cada posição revelava uma informação diferente. Essa é uma das possíveis justificativas de mãos e pés serem tidas como partes tão valiosas, afinal, seriam 
um canal de conexão com o mundo espiritual acessado através dos ossos de quem foi um grande chefe espiritual em vida.

Prosseguindo a investigação, agora com a obra de Antonio de Oliveira de Cadornega, o autor também descreveu algumas situações nas quais esteve em contato com os ngangas em Angola. O primeiro trecho em que ele menciona estes curandeiros é o seguinte:

Em o primeiro e segundo tomo da nossa História General das Guerras Angolanas tocamos algumas couzas dos abuzos e ritos gentilicos, que guarda e observa esta Ambundaína de Angola e quilombos dos Jagas da raynha Ginga, de Casangi e de Cabucu, e de outros que há em as províncias do Libolo, e tudo o que huns e outros observão vem a ser huma couza: agora diremos algumas de mais vulto, que este gentio ambundo observa, que para se escrever e explicar tudo, houvera mister hum grande volume; e assim diremos o que o gentio desta Ethyopia tem por costume guardar, excepto os que são bautizados e vivem entre os portuguezes; os de mais dão adoração ao Diabo, venerandoo e idolatrando nelle, tirando a devida adoração a Deos, como criaturas suas, invocando e chamando aquelle pay das trevas infernaes, deixando o Criador de todas as couzas pella criatura, pedindolhe remedio em suas necessidades e trabalhos e enfermidades, obrigando, com seus sacrifícios e offerendas e bayles deshonestos a lhes vir fallar, tendo para isso seus feiticeiros e gangas, que têm mais mão com elle e são mais seus mimozos pellas maldades que obrão, consultando por via destes seus privados, suas doenças e afflicçoens, ao que lhe dá por tão boas vallias, suas soluçoens, mostrandolhes ou ensinandolhes paos e hervas para suas curas; e no que consultão em suas differenças, lhes diz algumas couzas, com apparencia de verdade; e com huma madura lhe dá muitas verdes, tudo afim de os enredar e levar ás suas profundezas (CADORNEGA, III Tomo, 1972, p. 259).

No fragmento apresentando, percebe-se que o autor faz uso da palavra ganga, então, é preciso dizer que esta variação também fala exatamente dos homossexuais de foco deste estudo. É perceptível, na obra do soldado português, o tom de depreciação da cultura do povo mbundu, aos quais ele também chama de "gentio desta Etyopia". Há também a demonização da religiosidade dos povos da terra, uma prática comum entre os europeus que julgavam suas identidades culturais superiores às demais. As expressões de fé dos africanos, num geral, foram frequentemente atribuídas ao Diabo, pois a dinâmica da Igreja Católica era/é silenciar outras religiosidades. Por influência católica, a visão cega e dicotômica portuguesa não permitia uma leitura alternativa de outra cultura que não tendesse para a atribuição dela às forças de Deus e do Diabo. Prosseguindo, em outro momento, o autor traz mais contribuições relevantes sobre os ngangas. Ele diz que:

Há também entre este gentio muita sodomia, tendo huns com outros suas immundicias e sugidades, vestindo como mulheres; e lhes chamão pello nome 
da terra quimbandas; os quaes no destricto ou terras onde os há, têm communicação huns com outros; e alguns delles são finos feiticeiros, para terem tudo máo; e todo o mais gentio os respeita e os não offendem em couza nenhuma, e se succede morrer algum daquela quadrilha, se congregão os mais a the vir dar sepultura, e outro nenhum lhe bole, nem chega a elle, salvo os daquella negra e suja profissão; e quando o tirão de caza para o enterrarem, não he pella porta principal, senão abrem porta por de traz da caza, por onde sahem com elle fora, que como se servio pela do quintal, querem que morto saya também por ella; esta casta de gente he quem os amortalha e lhe dá sepultura, e não chega outro nenhum a elle como dissemos, que não seja de sua ralé; andão sempre de barba rapada, que parecem capoens, vestindo como mulheres (CADORNEGA, III Tomo, 1972, p. 259).

Este é o momento em que o autor português mais detalha os ngangas nos três tomos de sua obra. Cadornega apresenta a mesma surpresa que Cavazzi ao registrar que os outros habitantes não reprovam e nem ofendem os curandeiros. Apesar de tendencioso, o texto toca em pontos como os contatos sociais dos ngangas, seus costumes e também como realizavam seus funerais. Cadornega usa o termo "finos feiticeiros", o que traz a necessidade de dizer que para a consciência eurocêntrica cristã daquela época o conhecimento sobre plantas medicinais já era o suficiente para acusar uma pessoa de bruxaria/feitiçaria, por este motivo é preciso pensar além dos termos em si. Os contatos entre os ngangas aconteciam de forma contínua, pois faziam parte de um grupo social seleto dentro das comunidades ambundu. O ponto mais interessante do excerto acima é o funeral. Cadornega, assim como Cavazzi, menciona o quanto o funeral de um nganga era fechado, dizendo que só o grupo chegava até ele. Um detalhe interessante, presente na descrição do soldado português, é a referência feita entre a retirada do cadáver pela porta de trás da casa e o sexo anal. Como o nganga teria servido por trás em vida - sendo o passivo nas relações sexuais - a retirada do cadáver pela porta dos fundos teria uma simbologia muito forte para aquele grupo. É ainda correto afirmar que, na literatura e no aparato científico utilizados para este trabalho, verificou-se que os ngangas tinham que ser, necessariamente, passivos em suas relações sexuais como elemento de regra para viverem o seu ministério.

Cadornega detalhou de maneira muito interessante os ngangas. Até a forma como o autor deixou suas impressões particulares aparecerem no texto pode ser vista como uma possibilidade de interpretação que esteja além da obra em si. Os arranjos de palavras 
utilizados na elaboração do texto podem exprimir as emoções que o autor sentia no momento de escrita, detalhe este que pode servir também para análises de áreas como a psicologia, por exemplo. Apesar de não ser o foco deste estudo, é interessante mencionar possibilidades para outras áreas do conhecimento.

A ênfase dos dois autores europeus no fato dos ngangas não serem humilhados e ofendidos pelos demais habitantes demonstra que a homossexualidade era vista como algo natural dentro da cultura tradicional mbundu. Por desempenharem papéis de conselheiros, curandeiros e ervanários, os ngangas possuíam um enorme prestígio social. Voltando à obra de Cavazzi (196 p. 203), fica mais fácil entender a dimensão deste prestígio.

Pela autoridade que gozam todos esses ngangas, não há jaga, quer capitão na guerra, quer chefe de aldeia em paz, que não procure guardar algum deles consigo, sem o conselho de aprovação do qual não se atreverá a exercer nenhum ato de jurisdição nem a tomar qualquer resolução (CAVAZZI, 1965, p. 203).

Este fragmento serve para ilustrar, com palavras, quão grandes eram o prestígio e a liberdade que os ngangas possuíam no contexto mbundu. Os dois autores, cada um a sua maneira, tentaram registrar as suas impressões sobre aquele grupo de homossexuais que encontraram na Angola Antiga. Talvez muita informação tenha sido perdida ao longo dos séculos, restando poucas fontes, por este motivo tentou-se remontar a memória sobre os ngangas com base nas obras supracitadas, que podem ser consideradas algumas das fontes mais importantes sobre o assunto.

\section{Os ngangas e o silenciamento imposto pela moral católica}

A imposição da Igreja Católica na Angola Antiga foi um ponto de transformação na vida dos povos da terra e, consequentemente, na vida dos ngangas. Antes do contato com o invasor, o povo mbundu vivia suas tradições sem interferência, porém, foi o contato com os europeus e sua cultura religiosa que transformou o contexto de vida dos autóctones para sempre. A Igreja Católica nunca foi muito boa em aceitar percepções de mundo que não fossem consonantes às dela, por este motivo percebe-se que a demonização do continente africano, suas gentes e suas identidades culturais foi um processo longo que ainda deixa fagulhas na atualidade. Na verdade, a instituição religiosa 
supracitada perseguiu muitos povos por causa de suas culturas e crenças (VOLTAIRE, 2008). É preciso desconstruir a ideia de África elaborada pelas mãos brancas para entender que aquele continente é berço de grandes sabedorias e expressões humanas únicas.

Um ponto que não pode ser deixado de lado é a visão que os portugueses projetavam sobre Angola Antiga em um primeiro momento. Por ser um contexto completamente novo para os lusos, estes acreditavam que alguns traços típicos das sociedades europeias não fizessem parte dos sujeitos angolanos, como a homossexualidade, por exemplo. A "sodomia", como diziam os portugueses, deveria ser algo exclusivo da Europa. Mott (2005, p. 11) ilumina muito bem a negação da existência da homossexualidade na Angola Antiga quando diz que

\begin{abstract}
por trás do mito da inexistência do homoerotismo na África pré-colonial estão dois outros mitos não menos preconceituosos: a naturalização da sexualidade dos negros, que, movidos pelo instinto animalesco, desconheceriam os vícios antinaturais dos brancos e a superioridade física do primitivo africano, avesso à efeminação própria do mundo civilizado.
\end{abstract}

A negação europeia da existência da homossexualidade entre os povos africanos resulta de um pensamento errôneo e preconceituoso no qual “[...] a mulher africana é representada como emblema de fertilidade [e] o homem é identificado com a virilidade e a potência sexual" (BUSSOTTI; TEMBE, 2014, p. 19). Infelizmente, ao longo dos anos, a visão projetada sob os homens e mulheres de África foi a de que seriam símbolos sexuais, não havendo a possibilidade de outro comportamento que não fosse o heterossexual. Os ngangas aparecem como figuras importantes no contexto colonial para desconstruir a ideia da inexistência da diversidade sexual na Angola Antiga, colocando a visão europeia em cheque.

O silenciamento dos ngangas aconteceu depois da chegada dos missionários católicos na região da África Central Ocidental. A citada instituição religiosa se agarrou em duas passagens bíblicas para julgar a homossexualidade ao longo dos anos. A primeira delas está no livro de Levítico, capítulo 18 versículo 22, o qual diz que “com homem não te deitarás, como se fosse mulher; abominação é". A segunda passagem, no mesmo livro, diz que "se um homem se deitar com outro homem como quem se deita com uma mulher, ambos praticaram um ato repugnante. Terão que ser executados, pois merecem a morte" 
(LEVÍTICO, 20:13). As duas passagens supracitadas são as mais conhecidas quando o assunto é a condenação de pessoas que fogem ao padrão da heteronormatividade, pois foram elas que deram suporte para a condenação eclesial da homossexualidade.

A visão da Igreja Católica sobre a homossexualidade na Angola Antiga pode ser percebida em Istorica Descrizione de' Tre Regni Congo, Matamba et Angola, escrita pelo sacerdote capuchinho italiano Giovanni Cavazzi. Na obra, não são poucos os adjetivos que inferiorizam os ngangas, evidenciando o grau de aversão dos religiosos às figuras deles. É interessante pensar que talvez a homossexualidade não tenha sido o único problema visto pelos sacerdotes. O fato dos ngangas também serem chefes espirituais os colocava em posição de concorrentes em relação à Igreja Católica, pois professavam uma fé divergente e vasta em números de adeptos na região. É possível que a demonização especial que as figuras dos ngangas sofreram tenha acontecido não em decorrência apenas da expressão da sexualidade, mas também pelos papéis sociais que exerciam. É necessário pensar que "os missionários não eram somente servidores de Deus [...] doravante seriam agentes organizados em prol de um esforço nacional de aculturação, que tinha como objetivo exclusivo enfraquecer a posição cultural e comercial dos seus anfitriões" (AJAYI, 2010. p. 912). O esforço, naquele contexto, era para enfraquecer ao máximo a cultura dos povos autóctones para que eles recebessem mais facilmente os valores e a moral dos invasores europeus.

$\mathrm{O}$ ataque da Igreja Católica aos ngangas não significava apenas um ataque a um grupo de homossexuais, mas sim uma violência contra todo um sistema social já estabelecido. Ao atacar os ngangas, a espiritualidade mbundo também estava sendo atacada, o que enfraquecia a identidade cultural do citado povo e o deixaria em uma posição vulnerável de dominação sociocultural. A demonização da figura dos curandeiros pode ter acontecido também por um motivo religioso, mas não só. Eles eram figuras espirituais e políticas de grande poder e prestígio, por isso eram tão perigosos. A posição diferenciada que os ngangas possuíam frente aos demais de seu povo demonstrava que seriam inimigos em potencial para as autoridades políticas e eclesiais em Angola, por isso precisaram ser silenciados com veemência pelos sacerdotes católicos e demais autoridades. 
A sexualidade dos ngangas e dos ambundu, apesar das fontes históricas, carece de mais investigações. As descrições convergem sobre a figura dos curandeiros quanto aos longos cabelos (AGUALUSA, 2015) e a tomada de funções que seriam atribuídas às mulheres naquele contexto mbundu (Século XVII), porém, há lacunas. São contemplados nas obras históricas e na obra literária desta investigação apenas aqueles que apresentavam uma aparência diferente da recorrente ao homem cis padrão da época. "É tido como "natural" que o homossexual masculino seja "afeminado" [...]" (FRY; MACRAE, 1985, p. 11), talvez pelo fato de que seja mais fácil reconhecer a sexualidade de alguém que a exponha, porém, aplicando estas palavras ao contexto angolano antigo, é preciso dizer que podem ter existido ngangas e/ou outros LGBTTQIA+ que não fossem afeminados e que não tenham sido documentados pelo fato de não terem sido percebidos pelos europeus.

É preciso ainda dizer, e neste momento saindo um pouco unicamente do contexto mbundu, que a diversidade sexual na África Antiga foi percebida em diversas comunidades, evidenciando a naturalidade da expressão sexual além do padrão heterossexual naquele continente. Neil (2009, p. 54) ilumina bastante esta questão quando diz que

entre as várias tribos em que papeis homossexuais ou trangêneros foram relatados estão os Nandi do Quênia, os Dinka e Nuer do Sudão, os Konso and Amhara da Etiópia, os Ottoro da Nubia, os Fanti de Gana, os Ovimbundu de Angola, os Thonga do Zimbabwe, os Tanala e Bara de Madagascar, os Wolof do Senegal e os Lango, Iteso, Gisu e Sebei de Uganda, entre outros.

O foco desta pesquisa são os ngangas, entretanto, é válido salientar que várias foram as formas e as localidades onde se percebeu a diversidade sexual na África antes da imposição e do silenciamento praticados pelos europeus. Foi este contato que fez com que a percepção dos povos da terra mudasse em relação às várias expressões da sexualidade. Nesse sentido, a Igreja Católica possuiu um papel importante, pois estava presente naquele contexto julgando a homossexualidade e práticas tradicionais africanas como reprováveis (MOTT, 2005), fato que contribuiu para o enfraquecimento dos sistemas sociais locais. Os ngangas ambundu, por serem homossexuais e terem exercido a religiosidade tradicional local, foram alguns dos personagens daquela conjuntura sóciohistórica demonizados de maneira mais inflamada.

Vol. 03, N. 11, Jul. - Set., 2020 - http://periodicoscientificos.ufmt.br/ojs/index.php/rebeh/index 
Com o avanço dos processos de dominação cultural, política e religiosa protagonizados pelos europeus, os ngangas foram gradualmente perdendo o prestígio social que tanto tempo levaram para conquistar. Após a disseminação da moral católica em Angola, a demonização dos ngangas consolidou-se rapidamente, rendendo a eles perseguições e morte. Opoko (2010. p. 612) faz considerações pontuais sobre o choque religioso quando diz que "de modo geral, tornar-se cristão significava, em larga medida, deixar de ser africano e tomar como ponto de referência a cultura europeia. O cristianismo exercia, portanto, uma força desagregadora sobre a cultura africana". A Igreja Católica, de acordo com o exposto anterior, foi uma instituição que desconstruiu a identidade sociocultural mbundu e a reconstruiu, de certa forma, dentro de seus interesses. A assimilação da cultura invasora aconteceu lenta e gradualmente, mas efetivou-se. Neste novo espaço, onde a cultura tradicional dos autóctones não possuía mais lugar, os ngangas não gozavam mais de um local social e este talvez tenha sido o ponto final para eles.

\section{Considerações Finais}

Os ngangas ambundu, apesar de ainda serem tão desconhecidos, são figuras histórico-literárias muito importantes. Estes curandeiros e ervanários homossexuais de Angola Antiga, como são descritos, foram sujeitos que protagonizaram papéis importantíssimos dentro das comunidades onde viviam. Além de promotores da saúde pública, os ngangas eram autoridades espirituais e conselheiros dos chefes de Estado. Obviamente possuíam locais sociais de grande importância, fato que desconserta a ideia de que a homossexualidade e outras sexualidades sempre foram tidas como um desvio ou comportamento reprovável. Ressalta-se também que, apesar do uso recorrente do termo "homossexual" neste trabalho, se reconhece que os ngangas de Angola também podem se encaixar nas definições da transexualidade e/ou outras. Esta investigação, portanto, não desejou ser uma verdade final, mas sim uma abertura para questionamentos sobre os papéis importantes dos ngangas, retirando-os das sombras do desconhecimento.

A imposição da moral católica, sem dúvidas, foi um ponto crítico na existência dos antigos ervanários angolanos, sendo que este acontecimento provavelmente os levou a abandonarem suas práticas religiosas e buscarem maneiras de se readequarem ao novo contexto. É bastante possível que tenham existido aqueles que tentaram resistir às 
investidas sociorreligiosas européias, porém, o mais certo é que tenham sido perseguidos e massacrados, uma vez que naquele contexto de invasões todo sujeito que se atrevesse a não aceitar as convenções impostas seriam silenciados de uma ou outra forma. A assimilação da homossexualidade como algo reprovável se enraizou na cultura angolana, pois foi somente em 2019 que ela deixou de ser crime naquele país (QUERINO, 2019).

Reascender temas como a presença dos ngangas na literatura e na história permite uma iluminação interessante da homossexualidade em tempos passados, o que pode colaborar para a compreensão da diversidade na atualidade. Se para o povo mbundu os espíritos dos ancestrais davam suporte na batalha contra os inimigos, na atualidade podemos dizer que os espíritos dos ngangas ambundu dão suporte para a diversidade sexual em tempos modernos na luta contra o silenciamento e a homofobia. Buscar compreender estes sujeitos é uma obrigação na atualidade, pois é somente com luta e conhecimento que a homossexualidade e outras formas de expressão da sexualidade e dos gêneros serão compreendidas como traços naturais humanos.

Trevisan (2007, P. 188) afirmou que "tanto faz utilizar os termos gay, homossexual ou homoerótico, pois ainda a sociedade vê o homossexual como doente e anormal". Por motivos como os apresentados pelo autor é que a academia tem a necessidade e a obrigação de reconstruir o passado de sujeitos que fugiram às regras da heteronormatividade para desenhar uma nova consciência na qual as expressões diversas do desejo e da afetividade dos humanos sejam concebidas como naturais de nossa espécie. Dar voz aos homossexuais do passado é abrir novos caminhos para que a luta pela igualdade alcance o seu objetivo no presente e no futuro.

\section{Referências}

AGUALUSA, José Eduardo. A Rainha Ginga: e de como os africanos inventaram o mundo. Rio de Janeiro: Editora Foz, 2015.

AJAYI, Jacob Festus Adeniyi. História Geral da África VI: África do Século XIX a década de 1880. editado por J. F. A. Ajayi. Brasília: UNESCO, 2010. 
BÍBLIA, A. T. Levítico. In BÍBLIA. Português. Sagrada Bíblia Católica: Antigo e Novo Testamentos. Tradução de José Simão. São Paulo: Sociedade Bíblica de Aparecida, 2008.

BUSSOTTI, Lucas; TEMBE, António. A Homossexualidade na conceção afrocentrista de Malefi Kete Asante: entre libertação e opressão. Revista Ártemis, Vol. XVII n n 1; janjun, 2014.

CADORNEGA, Antônio de Oliveira de. História Geral das guerras Angolanas. Agência Geral das Colônias, 1972, I, II e III Tomos. [escrito no ano de 1680, em Angola].

CARVALHAL, Tânia Franco. Literatura comparada. 4.ed. revisada e ampliada. São Paulo: Ática, 2006.

CAVAZZI, Giovanni Antonio. Istorica Descrizione de tre Regni Congo, Matamba et Angola. Ed. Fortunato Alamandini. Bolonha: Giacomo Monti. 1687; Milão, 1690.

FRY, Peter; MACRAE, Edward. O QUE É HOMOSSEXUALIDADE. Coleção Primeiros Passos, SP. Brasiliense, 1985. Disponível em: http://www.giesp.ffch.ufba.br/Textos\%20Edward\%20Digitalizados/4.pdf Acesso em: $15 / 03 / 2020$

GALLIANO, Alfredo Guilherme. O método científico: teoria e prática. São Paulo: Harbra, 1979.

MOTT, L. Raízes Históricas da Homossexualidade no Atlântico Lusófono Negro. Conferência The Lusophone Black Atlantic in a Comparative Perspective, Centre for the Study of Brazilian Culture and Society, King's College. 2005 (pp. 10-11). Londres. Disponível em: https://portalseer.ufba.br/index.php/afroasia/article/viewFile/21099/13982 Acesso em: 10/04/2020.

NEILL, James. The Origins and Role of Same-Sex Relations in Human Societies. Jefferson: McFarland \& Company. 2009.

OLIVEIRA, Fabrício de Souza de; MADRUGA, Zulma Elizabete de Freitas. Ciência e Religião: a matemática nos jogos de búzios. In: Anais do XVIII Encontro Baiano de 
Educação Matemática. Ilhéus, Bahia. XVIII EBEM. 2019. Disponível em: https://casilhero.com.br/ebem/mini/uploads/anexo_final/516dd20592b0e899123dd29a2 e701eb7.pdf Acesso em: 10/04/2020

OPOKU, K. A. A Religião na África durante a época colonial. In: História geral da África, VII: África sob dominação colonial, 1880-1935. Edição Albert A. Boahen. 2.ed. rev. Brasília: UNESCO, 2010.

QUERINO, Rangel. Homossexualidade deixa de ser considerada crime em Angola.

ObservatórioG. 24 de Janeiro de 2019. Disponível em: https://observatoriog.bol.uol.com.br/noticias/2019/01/homossexualidade-deixa-de-serconsiderada-crime-em-angola Acesso em: 02/04/2020.

SILVA, Joaquim. História do Brasil para o Quarto Ano Ginasial. São Paulo - SP: Companhia Editora Nacional. 1943.

SOUZA, Eneida Maria de; LYZARDO-DIAS, Dylia; BRAGANÇA, Gustavo Moura (Orgs.). Sobrevivência e devir da leitura. Belo Horizonte: Autêntica Editora, 2014.

TREVISAN, João Silvério. Devassos no Paraíso: a homossexualidade no Brasil, da colônia à atualidade. Rio de Janeiro: Ed. Record, 2007.

VOLTAIRE [1694 - 1778]. Dicionário Filosófico. Tradução Ciro Mioranza e Antônio Geraldo da Silva. São Paulo: Editora Escala, 2008.

\title{
The Social Roles of Male Homosexuals in Ancient Angola:
}

a comparative analysis of ngangas in literature and history

\begin{abstract}
Male homosexuality, despite the lack of knowledge, was a reality in Ancient Angola. The ngangas were healers, counselors and homosexual spiritual leaders who had great social prestige in the mbundu society. The silencing of these subjects in the ancient Angolan context happened after the presence of the Catholic Church in that space. With the imposition of Christian morality, the social systems of the local peoples were partially or totally dissolved. This work aims to rescue the memory of ngangas ambundu and illuminate the theme of male homosexuality in Ancient Angola, elements erased by the Portuguese invasion. The justification for this investigation is the need to know the past
\end{abstract}




\section{( 근튼 \\ REVISTA BRASILEIRA DE ESTUDOS DA HOMOCULTURA}

of sexual diversity, or part of it, in order to try to understand it in the present. It is hoped that this work will be a contribution to future research that also aims to illuminate the past of homosexuality in Angola and / or in any other location in the globe.

Keywords: Nganga. Homosexuality. Ancient Angola. Silence. Catholic church.

Recebido: 01/05/2020

Aceito: 01/12/2020 